\title{
ADMINISTRAÇÃO PÚBLICA E SUA RELAÇÃO COM OS PRECEDENTES JUDICIAIS
}

\section{PUBLIC ADMINISTRATION AND ITS RELATIONSHIP WITH JUDICIAL PRECEDENTS}

CELSO HIROSHI IOCOHAMA

Doutor em Direito (PUC-SP), Doutor em Educação (USP), Mestre em Direito (UEL) e Especialista em Docência do Ensino Superior (UNIPAR). Professor do Curso de Graduação em Direito e do Mestrado em Direito Processual Civil e Cidadania da Universidade Paranaense - UNIPAR. celso@prof.unipar.br

FLAVIO DE ARAUJO

Mestre em Direito Processual Civil e Cidadania pela Universidade Paranaense. Especialista em Gestão e Legislação Tributária pelo Centro Universitário Internacional. Graduação em Direito pela Universidade Católica Dom Bosco, Advogado Público. Advogado. adv araujo12@hotmail.com

\section{RESUMO}

Os precedentes judiciais, conforme exposto no artigo 927 do Código de Processo Civil, impõem a necessidade de observância aos julgados de cortes superiores, tanto na perspectiva persuasiva como na vinculativa. Para aplicação do precedente judicial na administração pública, em uma seara extraprocessual, deve-se concretizar uma ponte formatada pelo texto constitucional que dê azo à utilização dos precedentes judiciais no cotidiano da administração pública, para que assim se atinja uma integração do direito entre os poderes Legislativo, Executivo e Judiciário.

PALAVRAS-CHAVE: Precedentes Judiciais; Administração Pública; Constituição. 


\begin{abstract}
The judicial precedents, as set out in article 927 of the Code of Civil Procedure, impose the need observance of the superior court judges, both in the persuasive perspective as in the binding. For the application of the judicial precedent in the public administration, in an extra-procedural field, a bridge shaped by the constitutional text must be established that gives rise to the use of judicial precedents in the daily life of the public administration, so that this way the integration of the law between the powers is achieved. Legislative, Executive and Judiciary.
\end{abstract}

KEYWORDS: Judicial precedents; Public administration; Constitution.

\title{
INTRODUÇÃO
}

Os precedentes judiciais sempre ocuparam um espaço importante dentro dos debates doutrinários, especialmente agora, dada sua disposição no artigo 927 do Código de Processo Civil de 2015, onde se vincula, por meio dos precedentes judiciais obrigatórios, as decisões de juízes e dos Tribunais.

Essa tendência vinculativa das decisões judiais relacionada aos precedentes judiciais do Código de Processo Civil tem clara interferência do sistema da Commow Law, como também da própria modernização interpretativa relacionada a aplicação do direito jurisprudencial pátrio.

Nessa esteira, torna-se importante analisar como esta sistemática de precedentes judicias obrigatórios irá impactar no cotidiano da administração pública sobretudo no aspecto extraprocessual, ou seja, na perspectiva de quais precedentes serão aplicados e como a administração recepcionaria as razões de decidir de um julgado, para fins de agir conforme o decidido judicialmente.

Tal indagação nasce na medida em que se observa no texto constitucional a necessidade de a administração pública atuar conforme a lei e respeitar a separação dos poderes e o princípio democrático.

Por outra banda, caso não aplicado o entendimento do precedente judicial na atividade administrativa, poderia se admitir a fragilização do princípio da igualdade, 
posto que, estariam munidos do conteúdo decisório do precedente só aqueles que se socorreram na jurisdição?

Importante salientar que a discussão não reside na vinculação da Administração Pública a precedentes judiciais que já possuem assento constitucional, como é o caso, por exemplo, das súmulas vinculantes e o controle concentrado de constitucionalidade.

Nessa dimensão, questiona-se se os precedentes judiciais obrigatórios conforme catalogados pelo artigo 927 do Código de Processo Civil de 2015 teriam força vinculativa direta no modo de atuar da Administração Pública ou necessitariam de uma ponte normativa entre os poderes.

Para isto, o presente artigo, abordará, ainda que de forma sintética, o impeditivo imposto pelo princípio da legalidade para incidência direta do precedente obrigatório na Administração Pública em um ambiente de Civil Law, e a possibilidade da integração do direito entre os poderes, em nome da igualdade e coerência, utilizando-se para tanto uma ponte normativa que tenha a formatação adequada para introduzir a ratio decidendi do precedente judicial no modo de agir da administração.

\section{RELATOS SOBRE O COMMOW LAW}

A sistemática jurídica dos países onde vigora a Common Law pauta-se pelos costumes jurídicos para resoluções dos conflitos. Logo, as estruturas legais formadas pelos processos legislativos não se apresentam como a principal fonte para resolução dos conflitos entre as partes, conforme acontece na Civil Law.

Observe-se que o fato de preponderar na Common Law o método baseado em costumes, levando em conta critérios como a razoabilidade e senso de justiça do julgador, não quer dizer que a legislação seja algo sem expressão e eficácia e que a criação do direito remanesça tão somente nas decisões dos juízes.

Posto isto, não é demais afirmar, que o Juiz do sistema da Common Law não cria direito a partir do nada, cabendo considerar, ainda, que nos países de tradição Common Law a estrutura jurídica não está consubstancia somente nas decisões judiciais (PUGLIESE, 2016, p. 36). 
Por certo, não é adequado o entendimento de que a cultura do sistema onde vigora a Common Law rejeita os atos legislativos escritos. Todavia, pode a jurisdição dar interpretação em desconformidade com o conteúdo legal, como também criar o direito na falta de previsão legislada.(PUGLIESE, 2016).

Quanto o Common Law e a doutrina do precedente é "importante destacar que não são figuras sinônimas na medida em que aquele trata de um sistema jurídico específico baseado em costumes, donde por vários séculos existiu sem a presença deste" (PUGLIESE, 2016, p.35).

Ademais, a doutrina do stare decisis não está delimitada apenas por um sistema do Common Law, visto que outros sistemas jurídicos também comungam da mesma prática.

Nessa linha, Luiz Guilherme Marinoni aponta que "não se deve confundir Common law e stare decisis, pois são independentes, sendo aplicável de forma mais visível perante a característica daquele" (MARINONI, 2013, p.31-32).

Entretanto, para sustentar tal afirmativa, torna-se imprescindível, ainda que de forma breve, fazer-se uma digressão histórica sobre a Common Law que remonta a época medieval.

A criação do Common Law no Direito Inglês tem como um de seus marcos históricos a conquista da Normandia, que através de Batalha de hastings, acabou por culminar na centralização do poder governamental como também o da administração da justiça (BARBOZA, 2014).

Assim, com a centralização da justiça e do poder governamental os normandos criaram:

Cortes Reais e um sistema de justiça real que gradualmente foi substituindo as antigas Cortes e regras feudais. Nesse processo de centralização da justiça, os juízes desenvolveram novos procedimentos e remédios, bem como um novo corpo de direito substantivo que seria aplicado a todos os cidadãos ingleses, o que justifica o nome de common law, como direito comum a todos, em oposição aos costumes locais. Ou seja, common law significa o direito comum a todo o Reino da Inglaterra, comum justamente porque se decidia de maneira centralizada pelas Cortes Reais de justiça de Westminster. Desse modo, o common law se opunha a todos direitos locais que se baseavam nas tradições e eram distintos de um local para outro. (BARBOZA, 2014, p.41). 
Logo, não seria temerário afirmar que a origem da Common Law não está galgada no respeito aos precedentes, mas sim em uma centralização de poder, inclusive judicial, que por sua vez, através das Cortes Reais, produziam e emanavam o direito por meio de seus julgamentos para todo Reino da Inglaterra.

Nesta toada, percebe-se que a tônica do Common Law tem seu 'DNA' intrinsicamente ligado com a perspectiva de um sistema judicial que centraliza para si a prerrogativa da criação do direito para resoluções de casos.

Ademais, o Common Law no período medieval não derivava de um sistema de precedentes baseados nas razões de decidir, mesmo porque as discussões integrantes das decisões não tinham registros escritos que pudessem dar base para outras decisões futuras (PUGLIESE 2016).

Os tribunais até observavam as decisões passadas, entretanto tal observância não era vinculante. Acontece que tal entendimento foi se modificando com o passar do tempo, senão vejamos:

\footnotetext{
Essa realidade passou a se alterar na segunda metade do século XVI, no início do período Tudor. Os juízes adotaram uma postura de determinar o direito pelas decisões anteriores e, principalmente, pelas razões que passavam a ser registradas. No entanto, o valor das decisões não era determinante para o resultado, mas meramente informativo (PUGLIESE, 2016, p.35).
}

Já no século XVII, os precedentes foram cada vez mais sendo analisados, todavia sem ter uma obrigatória observância, visto que somente no século XVIII foi constatada a moderna doutrina dos precedentes (PUGLIESE, 2016).

Assim, é razoável apontar que a doutrina dos precedentes não se originou de forma concomitante com a Common Law, sendo que seu reconhecimento como instrumento necessário para construção do direito, viria a surgir após centenas de anos e várias mutações do sistema já existente.

Fica assim demonstrado, ainda que brevemente, os indícios históricos da formação da Common Law.

Aproximando-se da tratativa do artigo, revela-se salutar trabalhar com o contexto do Common Law na perspectiva jurisdicional e os seus reflexos, notadamente, sobre adoção da doutrina dos precedentes. 
Nesse sentido, o processo na jurisdição onde a formatação é de Common Law, já com a introdução dos sistemas de precedentes, as dúvidas e problemáticas são resolvidas dentro de uma metodologia baseada na observância ao case law (DAVID, 2002).

Logo, em regra, a força normativa emitida pela jurisdição é consubstanciada no aparato jurisprudencial que fornecem por sua vez a ratio decidendi vertidas pelos tribunais superiores e não de um modelo normativo estanque baseado em regras escritas (DAVID, 2002).

Nas palavras de Tucci:

O direito declarado na ratio decidendi, sendo claramente vinculante para todas as cortes inferiores e todos os súditos do reino, se não fosse considerado igualmente vinculante para os Law Lords, a House of Lords se arrogaria o poder de alterar o direito e legiferar com autônoma autoridade (TUCCI, 2010, p. 220).

Contudo, não há que se levar a cabo, que nos países de tradição de common Law, toda normatização aconteça a partir das ratio decidendi produzidas pelos tribunais superiores, sendo que, existe também nestes países uma gama considerável de legislação aplicável a jurisdição que produz seus efeitos mesmo diante do sistema de precedentes vinculantes (OLIVEIRA, 2017).

Desse modo, não é demais afirmar, que existe uma aproximação dos sistemas da Common Law e Civil Law.

Ainda em relação ao common law, é imperioso destacar, a função da decisão judicial, que é de estabelecer os precedentes judiciais como parâmetro para o julgamento de casos análogos posteriores, que serão, em regra, julgados da mesma forma.

Todavia, para aplicação dos precedentes, tornou-se necessário a criação de técnicas que dessem base para sedimentação aos conteúdos decisórios jurisdicionais. Nesse sentido Weber Luiz de Oliveira explana:

Foram criadas e consolidadas técnicas de julgamento que objetivam aplicar e manter um entendimento passado para caso presente semelhante. Dessas técnicas ou conceitos podem ser referidos, uma vez ligados ao entendimento de precedentes, objeto da pesquisa, o stare decisis, a ratiodecidendi, o obter dictum, o distinguishing e o overruling (Oliveira, 2017, p.41). 
Assim, resta evidente que a técnica do precedente foi se desenvolvendo dentro do sistema jurídico do Common Law, onde foram aplicadas técnicas vocacionadas a permitir uma segurança jurídica e a estabilidade do direito por meio das respostas jurisdicionais.

\title{
3 RELATOS SOBRE A CIVIL LAW
}

A característica marcante dos países onde vigora a sistemática de Civil Law é a o da imperatividade dos comandos normativos produzidos através de processos legislativos, logo, a legislação é consagrada como principal fonte do direito.

Todavia, é importante salientar, sem maiores digressões, que essa característica de predominação da lei em relação a outros modelos normativos, nasceu de um processo histórico que compreende dois momentos distintos, sendo eles, a descoberta de textos jurídicos romanos no século XI e o segundo oriundo da Revolução Francesa, conforme explica Tereza Arruda Alvim:

\begin{abstract}
O direito que existe nos países de civil law, no entanto, é fruto de dois momentos históricos cujas consequências são nitidamente perceptíveis hoje. $\mathrm{O}$ primeiro deles foi quando, no século $\mathrm{XI}$, descobriram-se textos jurídicos romanos, que haviam sido conservados durante a Idade Média, e começaram a ser reestudados no norte da Itália, principalmente em Bologna. Abusos, relativos a privilégios excessivos dos nobres e do clero, somados à vulnerabilidade dos juízes, acabaram desembocando na Revolução Francesa, que, acredito, foi o segundo e principal movimento histórico responsável pelas feições que o direito tem hoje nos países de civil law (2010, p. 3).
\end{abstract}

Observa-se, que foi determinante para criação do sistema do Civil Law o fato histórico da revolução, pois ocorreu ruptura no sistema vigente, diferentemente do Common Law onde não houve esta ruptura através de revolução.

Os processos históricos diferenciados onde na Civil Law houve uma ruptura e no Common Law visualiza-se continuidade, foram determinantes na construção de sistemas tão diversos (DAVID, 2002).

Nota-se que no Civil Law busca-se por meio de edição de comandos normativos pré-constituídos uma regulamentação da atividade humana, que vertem 
abstração e generalização vocacionadas a resolver inúmeras controvérsias na orbita das relações sociais.

No Brasil, a cultura Jurídica é ligada a Civil Law originada no reduto romano - germânico, sendo assim de características fortemente legalistas. Nessa linha, explica Lenio Luiz Streck que "no ordenamento jurídico brasileiro, filiado ao sistema romano-germânico, ocorreu um movimento similar ao ordenamento jurídico da França e da Alemanha, que pretendia construir o Direito baseado no code. Portanto, no direito brasileiro, a rigor, a fonte primordial é a lei" (STRECK, 1998, p. 77-78).

Assim, evidencia-se que o ordenamento jurídico brasileiro se baseia em um sistema positivado incumbido de regulamentar as condutas humanas através da generalidade e abstração, contidas no bojo das leis.

Entretanto, não é certo afirmar que o Direito brasileiro permanece absolutamente fechado, visto que existem fissuras que reconhecidamente, até mesmo por meio de lei, dependem da observância da analogia, princípios gerais do direito e dos costumes, conforme art. $4^{\circ}$ da Lei de Introduções às normas do Direito Brasileiro, Decreto-Lei n. 4.657, 4 de setembro de 1942.

Porém, é necessário entender, que tais mecanismos são considerados fontes secundárias, na medida em que são operacionalizados principalmente quando configuradas as lacunas no texto normativo, mantendo assim a lei suas características imperativas dentro do sistema normativo brasileiro, sendo importante considerar o respeito à legalidade, dentro de uma perspectiva sistemática do Código de Processo Civil, sem desprezar a importância interpretativa que tais fontes podem somar para a compreensão dos fenômenos jurídicos.

Neste contexto, quanto aos precedentes judiciais, inadequado seria sua inclusão de forma taxativa no rol de mecanismos secundários na busca de preenchimento de lacunas existentes no ordenamento jurídico. Na mesma direção Weber Luiz de Oliveira entende que:

É certo que, para aplicação das fontes secundárias, o artigo $4^{\circ}$ faz referência à lacuna da lei ('quando a lei for omissa', de modo que não se entende como adequada a inclusão da jurisprudência ou precedente judicial nesse preceptivo legal, porquanto a aplicação de precedente imprescinde de lacuna, vale dizer, não se aplica quando a lei for omissa tão somente, mas se aplica sobre ela e muitas vezes contra ela. Veja-se, por exemplo, a possibilidade de vinculação à interpretação conforme dada pelo Supremo Tribunal Federal em 
julgamento de controle concentrado de constitucionalidade (OLIVEIRA, 2017, p. 44).

Desse modo, deve-se repelir a ideia de que o precedente judicial tem como função precípua preencher vazios legislativos, posto que sua aplicação deve ser direcionada a impor ou dar devida interpretação ao conteúdo legal (OLIVEIRA, 2017).

Posto isto, resta plasmado que, na sistemática da Civil Law, o Direito advém da lei produzida através de processos legislativos e não de provimentos jurisdicionais, desse modo, a lei dentro deste sistema é de suma importância para a devida organização social e para o nosso regime político - institucional brasileiro, mesmo porque a legalidade dentro do texto constitucional possui patamar de cláusula pétrea.

\title{
4 QUANTO AOS PRECEDENTES JUDICIAIS
}

A operacionalização do mecanismo do precedente judicial como forma de resolução de conflito não está atrelada obrigatoriamente a só um modelo de sistema, haja vista, o precedente ser instrumento utilizado tanto no seio do Common Law como no Civil Law.

Todavia, não há que se negar, que a doutrina dos precedentes conforme a sistemática do Common Law, vem, dia após dia, sendo objeto de discussão dentro do contexto jurídico brasileiro, tanto é verídico isso que o próprio Código de Processo Civil de 2015 acabou impregnado por tal entendimento (OLIVEIRA, 2017).

Nessa linha Weber Luiz de Oliveira ressalta que:

\begin{abstract}
A historicidade do direito brasileiro, notadamente, com as últimas alterações do Código de Processo Civil de 1973, já seria suficiente para o estudo do precedente e sua aplicação para a Administração Pública. Contudo, vale também destacar que a prescindibilidade da análise do conceito e categorias do precedente na commow Law não se mostra adequada, porquanto, como prefacialmente descrito, é notória a influência do precedente vinculante na construção legislativa e doutrinária neste início de século no Brasil. (OLIVEIRA, 2017, p. 47).
\end{abstract}

Contudo, é de bom tom que a doutrina dos precedentes tenha sua análise atrelada à realidade brasileira, ou seja, que tal técnica faça parte de uma racionalidade 
jurídica que deve depreender-se da Constituição Federal. Logo, sua aplicabilidade deve observar as regras legisladas, para que não se ofenda o regime político conferido pelo próprio texto constitucional.

Desse modo, entende-se, que a interpretação do precedente deve ocorrer de forma sistemática, aferindo-se quando é possível a produção dos seus efeitos de forma direta ou quando vai de encontro com o regime constitucional adotado no Brasil.

Essa reserva quanto à aplicação do precedente no Brasil é salutar, especialmente, no que tange a Administração Pública, haja vista, que um dos pilares do regime jurídico administrativo é o da legalidade e não o precedente.

É lógico, que não se pretende defender um sistema totalmente fechado na lei, mesmo porque o próprio processo não está atrelado tão somente na legalidade, pois possui contornos de ampla interpretação à luz da constituição, característica essa, que está perfeitamente visível no Código de Processo Civil de 2015.

Nessa direção aponta, Hermes Zaneti Jr. e Carlos Frederico Bastos Pereira que:

\begin{abstract}
O fetiche da lei como fonte única do direito é ainda uma realidade no Brasil e que precisa ser revistada, sobretudo porque a norma de reconhecimento do sistema brasileiro não é mais o princípio da mera legalidade, e sim da legalidade ampla constitucional. ${ }^{19}$ Com o advento do novo Código de Processo Civil, a constitucionalização do processo dá novos contornos à aplicação do direito art. 1.․, CPC (LGLI2015\1656), sendo necessário quebrar definitivamente com dogmas ainda presos a um paradigma do Estado Liberal (2016, p. 37).
\end{abstract}

Dessa maneira, há que se trazer à baila, dentro de um contexto do direito, a ferramenta da interpretação, que exerce papel tão importante quanto o próprio texto legal, especialmente, na atividade jurisdicional ligada ao campo das decisões, visto que a função de julgar não prescinde de interpretação. Tal afirmação coaduna com o entendimento de que a lei não seria suficiente para abarcar todo um contexto social que sofre mutações com o passar do tempo, dada a complexidade e diferenças das relações sociais ou mesmo pela velocidade vertiginosa da própria tecnologia que anda a passos largos perante o texto normativo posto (ZANETI JR e PEREIRA, 2016, p. 40).

Não seria leviano afirmar, que essa função interpretativa dos Juízes não 
deriva apenas das situações em que a norma não comporta mais a realidade vivenciada, posto que, ela torna-se inafastável também em inúmeras situações em que a própria norma é confusa ou até mesmo, por estar a lei, em rota de colisão com outro texto legal de mesma envergadura.

Nesse sentido, revela-se como razoável que o texto normativo tenha sua significação reconstruída a partir da norma interpretada, principalmente nas situações em que o texto legal for insuficiente para o alcance do direito.

Nesse diapasão, vislumbra-se um terreno fértil para que uma decisão judicial que fora construída através da interpretação, reformate o conteúdo jurídico abstraído do texto legal, e constitua um possível precedente vinculante ou persuasivo, conforme se pode observar no Código de Processo Civil de 2015.

Sendo assim, é inadequada a posição que defenda que o precedente judicial venha ocupar o campo da norma legislada, ferindo assim princípios como a separação dos poderes e o democrático, tão caros para o nosso regime político constitucional. Nessa esteira reside a posição de Hermes Zaneti Jr. e Carlos Frederico Bastos Pereira:

\begin{abstract}
A criação da norma - geral e abstrata - é e continuará sendo uma prática privativa do Poder Legislativo, uma vez respeitado dentro do devido procedimento legislativo o aspecto formal, consistente na liberdade de conformação do legislador no âmbito de sua discricionariedade estrutural, e o aspecto material, correspondente à proteção ao núcleo essencial dos direitos fundamentais no âmbito de sua discricionariedade epistêmica. Por sua vez, a reconstrução da norma - geral e concreta - é tarefa ínsita à atividade jurisdicional em razão da impossibilidade de ser criada uma norma a partir do nada, do vácuo normativo, do vazio textual, devendo o Poder Judiciário reconstruir os significados normativos de acordo com a Constituição Federal, a legislação infraconstitucional e a tradição jurídica (art. $1 .$. do CPC/2015 (LGL\2015\1656)). Não é a intenção de um modelo de precedente proliferar o número de normas no ordenamento jurídico, pois não se quer introduzir no sistema normas gerais e abstratas equivalentes à lei, mas o que se busca é, por uma questão de racionalidade, vincular a solução jurídica de determinados juízes e tribunais às circunstâncias fáticas do caso concreto: é a vinculação aos material facts do caso que torna a normaprecedente geral e concreta e não geral e abstrata (2016, p. 37).
\end{abstract}

Repisa-se que o precedente não é método substitutivo do alcance geral e abstrato da norma legislada, sendo que, a sua eficácia para resolução de conflitos advém de um caso concreto onde a decisão produz uma interpretação qualificada do texto capaz de ser aplicada para casos análogos. 
Dessa forma, o precedente judicial no Direito brasileiro não está inserido em um patamar equivalente ao texto legal visto atuar em um espaço diferenciado ao qual a lei não tem capilaridade suficiente para dar resolutividade ao caso concreto.

José Miguel Medina, também entende como errônea a ideia de que uma decisão judicial tenha capacidade para criar o direito com as mesmas características da atividade legiferante, visto que, quando atividade jurisdicional precisa lançar mão de uma interpretação qualificada para resolver conflitos, utiliza-se da própria estrutura legal e constitucional existente, logo, não possui a jurisdição o poder de introduzir algo incompatível com o sistema jurídico adotado. (2016, p. 2).

O precedente judicial possui uma função de integridade, estabilidade e coerência do direito emanado pela jurisdição, propiciando assim, através de suas razões de decidir, uma racionalização da decisão judicial.

Todavia, é de suma importância que não se construa uma decisão judicial sem análise detida ao caso concreto, dando-se mais importância para a indagação do que para problemática judicial em mesa, no sentido de o julgador preocupar-se mais com os reflexos da decisão em casos futuros do que com o conteúdo da própria decisão.

Lamy e Vieira Luiz, (2015, p. 7), plasmam um exemplo que se encaixa perfeitamente com esta situação:

\begin{abstract}
A decisão do Supremo Tribunal Federal (STF) sobre a demarcação da reserva indígena Raposa Serra do Sol ${ }^{31}$ seria um bom exemplo brasileiro deste aspecto prospectivo, caso não houvesse a correção de rumo nos embargos de declaração. Isso porque, os votos dos Ministros ${ }^{32}$ e suas manifestações públicas ${ }^{33}$ davam conta da importância do julgamento não pela demarcação, em si, da reserva Raposa Serra do Sol, mas para a fixação de regras para as futuras demarcações. Em outras palavras, a preocupação da Corte não estava voltada nos fatos concretos da questão posta na decisão, mas aos reflexos deste próprio julgamento nos eventos futuros. Tanto que ao final do julgamento, sob o pretexto de fixar "salvaguardas constitucionais", o STF, por maioria de votos, estabeleceu dezenove regras gerais e abstratas (desvinculando-se do caso analisado) para as futuras lides sobre demarcação de terras indígenas.
\end{abstract}

Observa-se que os efeitos da decisão foram fragilizados com o julgamento dos embargos, onde ficou entalhado que os fundamentos aplicados naquela decisão não seriam de forma automática aplicados em casos análogos (LAMY E VIEIRA LUIZ, 2015). 
Assim, defende-se que o caráter somente prospectivo do precedente judicial quando produz normas gerais e abstratas, utilizando para tanto o caso concreto, tornase inadequado, visto não ser esse seu papel na construção do Direito.

O precedente judicial quando trabalha com a dimensão de criar normas gerais e abstratas acaba ocupando um lugar que constitucionalmente deveria ser regido por lei, e ainda perde suas características de dar estabilidade, coerência e uniformidade a jurisprudência, oportunizando assim um alto grau de subjetividade ao Juiz na hora de decidir.

Lamy e Vieira Luiz (2015, p. 3), ainda diferenciam que o direito produzido através da decisão judicial funciona em microescala onde a tese jurídica vai sendo aperfeiçoada caso após caso, formando-se assim uma cadeia interpretativa qualitativa quanto a Lei funciona em macroescala onde a legislação tenta abarcar todo um contexto social.

Assim, trabalhar o precedente judicial numa perspectiva meramente prospectiva acaba por afastar importantes fatores para qualificação da tese futura a medida em que se anula quase que totalmente a facticidade do caso e o critério de temporalidade, tão importantes na inovação das teses jurídicas.

É imperioso destacar que não está se afirmando aqui, que uma decisão de um caso não pode ser utilizada de parâmetro para uma gama considerável de situações similares, mas sim que este é um efeito reflexo e não principal na construção de uma decisão judicial.

Desse modo, a generalidade e abstração conferido ao caráter prospectivo do precedente judicial é indigesto à sistemática constitucional, visto ser esta uma tarefa da lei e não da jurisdição.

\section{QUANTO AO PRECEDENTE E A ADMINISTRAÇÃO PÚBLICA}

$\mathrm{Na}$ seara da administração pública torna-se imprescindível uma análise referente ao precedente tanto na sua perspectiva vinculante como em seu aspecto persuasivo para fins de se verificar quais os limites e possiblidades, e até mesmo obrigatoriedade, quanto a utilização dos precedentes na administração pública. 
Nesse diapasão, percebe-se, que 0 atributo do precedente persuasivo remanesce na utilização da ratio decidendi de uma decisão na fundamentação de outras decisões, mas não de forma obrigatória.

Ainda que essa tônica persuasiva do precedente possa ocorrer tanto de forma vertical quanto horizontal nos tribunais, vertical quando a irradiação de seus efeitos tem origem no órgão de hierarquia superior ao que emitira a decisão, e, horizontal quando a ratio decidendi que servira de parâmetro para o julgamento, pertencer ao próprio órgão prolator.

Por outra via, está o precedente obrigatório provido de vinculatividade, inclusive em relação aos poderes legislativo e executivo.

A vinculatividade da administração pública em relação aos precedentes ocorre eminentemente através de controle concentrado e súmulas vinculantes, conforme dispõe o $\S 2^{\circ}$ do artigo 102 e 103-A, ambos da Constituição Federal

Nesse sentido, Oliveira:

\begin{abstract}
O regramento de atos da administração pública, como visto, está primeiramente estipulado na Constituição Federal, nas respectivas constituições estaduais e, por fim, na legislação (leis, decretos, portarias, etc.). Em razão disso, necessário que o não atendimento a toda esta normatividade, constitucional e infraconstitucional , se dê dentro dela própria, com a inclusão de exceções ou regulamentações normativas que possibilitem o seu afastamento e maleabilidade ao caso em exame, como, por exemplo, atualmente se dá com a súmula vinculante e a decisão em controle concentrado de constitucionalidade, à exceção da arguição de descumprimento de preceito fundamental, tendo esses precedentes vinculantes aplicação direta na esfera administrativa (2017, p.165).
\end{abstract}

Aqui se começa a indagar qual seria o grau de vinculação da administração pública perante o precedente judicial, e para tal análise, torna-se imprescindível a observância do princípio da legalidade, o da separação dos poderes e ainda o princípio democrático.

Mas tal análise não terá o condão de utilizar-se destes princípios no intuito de negar a possibilidade de observância obrigatória do precedente na administração pública, mas sim de demonstrar mecanismos hábeis capazes de gerar integração do Direito dentre as esferas de poder.

Olvidar-se dos benefícios que o precedente judicial poderia trazer para o regime jurídico administrativo, embasando-se para tanto, no fundamento simplista da 
clássica conceituação de separação dos poderes e na legalidade estrita acabaria por trazer sensíveis prejuízos no que diz respeito à integração e coesão do direito.

É inegável a imensa densidade de demandas judiciais as quais a Administração Pública faz parte, onde não raras às vezes em que a respostas da jurisdição para essas demandas divergem entre si, gerando eterna insegurança jurídica no atuar da administração pública.

O setor público é o maior litigante nacional, figurando como parte em $51 \%$ processos, conforme pesquisa realizada no sítio do Conselho Nacional de Justiça (BRASIL, 2011).

Esta insegurança jurídica possui reflexo negativo imediato na medida em que o planejamento das ações administrativas acaba por esbarrar em tamanha incerteza, pois a falta de uma voz uníssona na interpretação do direito pela jurisdição causa dano tanto na falta de previsibilidade quanto no aumento das demandas judiciais.

Nesse sentido, Pugliese encarta em seu texto:

\begin{abstract}
O judiciário não interpreta e aplica as leis que regulamentam o Direito Público de modo uniforme, o Poder Executivo pode ter grande dificuldade em determinar suas áreas de atuação. Sem coerência e previsibilidade, a Administração Pública não teria um planejamento eficiente. Se essa afirmação é feita a respeito do Poder Executivo Federal dos Estados Unidos, o que dizer da administração pública brasileira, que é o maior litigante em todo território. Se houvesse uniformidade nas decisões, municípios, estados e a União poderiam planejar com mais segurança seus atos e, mais do que isso, não teriam razão para insistir em discussão judiciais pacificadas pelos tribunais superiores (PUGLIESE, 2016, p. 65).
\end{abstract}

Nessa esteira, é notório que as decisões do poder judiciário devem ser respeitadas, entretanto, para que isso ocorra de forma serena, a administração reclama um certo grau de uniformidade das decisões.

Um exemplo de uniformização que de fato expõe segurança jurídica reside nas súmulas vinculantes, senão vejamos:

Art. 103-A. O Supremo Tribunal Federal poderá, de ofício ou por provocação, mediante decisão de dois terços dos seus membros, após reiteradas decisões sobre matéria constitucional, aprovar súmula que, a partir de sua publicação na imprensa oficial, terá efeito vinculante em relação aos demais órgãos do Poder Judiciário e à administração pública direta e indireta, nas esferas federal, estadual e municipal, bem como proceder à sua revisão ou cancelamento, na forma estabelecida em lei (BRASIL, 1988). 
Desse modo, não se pode fechar os olhos para a necessidade de uma uniformização do Direito e da necessidade de sua integração entre os poderes. Mas isso não significa que a legalidade e a separação dos poderes devam ficar em segundo plano, visto não ser isto a conformação constitucional.

Há muito a doutrina de Direito Administrativo e o texto constitucional apontam para necessidade de os atos administrativos estarem diretamente vinculados a um comando normativo, conforme artigo 37 da Constituição Federal.

Nesse sentido, Celso Antonio Bandeira de Melo afirma:

Como é sabido, o liame que vincula a administração a lei é mais estrito que o travado entre a lei e o comportamento dos particulares. Com efeito, enquanto na atividade administrativa só se pode fazer o que é permitido. Em outras palavras, não basta a simples reação de não contradição, posto que, demais disso, exige-se ainda uma relação de subsunção. Vale dizer, para legitimidade de um ato administrativo é insuficiente o fato de não ser ofensivo à lei. Cumpre que seja praticado com embasamento em alguma forma permissiva que lhe sirva de supedâneo (MELO, 2010, p. 960).

Vislumbra-se que os atos administrativos são torneados conforme as delimitações legais e não para além delas, mesmo a discricionariedade administrativa não é inteiramente desvinculada, pois sempre tem em seu horizonte obrigatoriamente a finalidade pública a ser seguida.

Entretanto, em uma concepção atual, revela-se que 0 ato administrativo também existira quando inexistir lei, mas necessita ter em seu bojo uma sintonia com o texto constitucional em relação a seus princípios, como também em relação a efetivação dos direitos fundamentais.

Neste cenário de alargamento do conceito do princípio da legalidade e da superação do conceito clássico de separação dos poderes e ainda, com a necessidade latente de integração do direito entre os poderes, em benefício de uma isonomia e da segurança jurídica almejada por toda sociedade, indaga-se sobre a possibilidade de aplicação do precedente como baliza orientadora da atividade administrativa.

Como já visto, sabe-se que a legalidade funciona como um parâmetro obrigatório do atuar administrativo. Todavia, em nome de uma interpretação uniforme do direito, defende-se a possibilidade de criação de mecanismo regulamentador, em 
sentido lato, no intuito de recepcionar o entendimento plasmado na ratio decidendi do precedente judicial para sua utilização na confecção dos atos administrativos.

Tal mecanismo regulamentador é de suma importância na medida em que elimina o subjetivismo do administrador e agentes públicos na operacionalização de um precedente como base para decisões administrativas.

Oliveira, ainda acrescenta o critério de publicidade para aplicação do precedente judicial:

Ainda, dá publicidade às pessoas que determinada legislação será, doravante, aplicada consoante o que está sedimentado em precedente judicial. Esta mudança de entendimento não pode ser feita, portanto, de inopino, sem cientificação da sociedade, pois, como dito, o particular pode fazer tudo o que lei não proíbe e, esta permissão está atrelada ao sentido da lei. O inc. II do art. 5. da CF assim impõe. Se o sentido da lei era interpretado pela Administração de uma determinada forma, influenciando ou não as atividades privadas, a modificação da atuação estatal, em cumprimento ao princípio da moralidade, deve ser pública (2016, p. 9).

Dentro da seara do Direito Administrativo, em relação à administração pública, para a observância dos precedentes judiciais, torna-se necessária a publicidade sobre a recepção do precedente judicial, caso a administração o adote.

Essa conduta é derivada da respeitabilidade a "doutrina dos atos próprios" que verte a obrigatoriedade de a administração pública ter coerência em relação às suas condutas, observando o modus operandi de seus atos para aplicá-los com isonomia a terceiros nos casos similares e sucessivos.

A teoria dos atos próprios tem o condão de conferir estabilidade quanto aos atos da administração conferindo assim razoável segurança jurídica aos administrados, que não sofrerão com a mudança repentina dos atos da administração.

Nesse sentido, entalha Modesto (2007, p. 8), a chamada 'doutrina dos atos próprios', diz respeito à obrigação do sujeito titular de direitos ou prerrogativas públicas, de respeitar a aparência criada por sua própria conduta anterior nas relações jurídicas subsequentes, ressalvando a confiança gerada em terceiros, regra fundamental para a estabilidade e segurança no tráfego jurídico.

Assim, a adoção pela administração pública dos precedentes judiciais, como base orientadora, deve ser amplamente difundida entre os administrados, sob pena de se transmitir uma imagem de não coerência e instabilidade perante a sociedade. 
A publicidade do novo entendimento administrativo extraído dos precedentes judiciais é um desdobramento do princípio da segurança jurídica e o principio da proteção da confiança, pois o cotidiano tanto da seara pública como da privada, sofrem efeitos das normas legais entabuladas pela administração, necessitando assim de cientificação capaz de gerar previsibilidade para adequações que se fizerem necessárias ante a norma regente da matéria (OLIVEIRA, 2017).

Nessa toada, a regulamentação para aplicação dos precedentes judiciais pela administração pública é imprescindível para que se alcance a tão almejada integração e estabilidade do direito.

\section{INTEGRAÇÃO DO PRECEDENTE OBRIGATORIO JUDICIAL NA ATIVIDADE DA ADMINISTRAÇÃO PÚBLICA}

Em uma análise ao contexto constitucional atual observa-se a necessidade de superar-se o entendimento de uma aplicação tão somente literal da lei, visto que, o princípio da legalidade estrita não é capaz por si só de dar suporte a grande gama de relações do cotidiano.

Isso não significa que o conteúdo legal deva ser desprezado em benefício de uma interpretação judicial advinda de um precedente obrigatório. Não seria adequado que existisse aplicação de um precedente obrigatório na atividade administrativa, sem que para isso houvesse uma regulamentação específica que desse segurança jurídica e conferisse a respeitabilidade necessária ao princípio democrático à separação dos poderes e o da legalidade.

Todavia, a não aplicação do entendimento do precedente obrigatório para aqueles que não buscaram a guarida jurisdicional, seria um verdadeiro atentado à igualdade no trato com a sociedade, e teria efeito prejudicial tanto na integração do direito como na resolução de conflitos as quais a administração pública possa a vir a figurar como parte.

Nessa medida, para estabilização do Direito entre o Judiciário, o Legislativo e o Executivo, especialmente no tocante ao precedente obrigatório, imprescindível se torna um mecanismo regulamentador que confira legalidade ao conteúdo da ratio 
decidendi do precedente para sua aplicação do cotidiano administrativo.

É lógico que tal regulamentação é prescindível nos casos de precedentes vinculantes relacionados a súmula vinculantes e as decisões em controle concentrado de constitucionalidade, haja vista que, para essas situações, a aplicação é direta do precedente vinculante em relação à administração pública.

Então, para dar conformidade a texto constitucional, a aplicação do precedente obrigatório no bojo do regime jurídico administrativo clama por regulamentação de envergadura constitucional, sendo que, seria inadmissível uma norma processual de competência da União, que é o diploma processual civil, suplantar as competências conferidas pelo próprio texto constitucional aos entes federativos.

Entretanto, não se pode dar amparo a uma ideia de que o próprio Poder Executivo estaria apto a regulamentar a recepção de um precedente judicial obrigatório, visto ser uma tarefa eminentemente legislativa (OLIVEIRA, 2017, p. 5)

Neste espaço, poderia afirmar-se que a regulamentação deva ser produzida através de lei, entretanto, indaga-se, lei ordinária, complementar ou delegada? A opção adequada seria de lei complementar que demanda um quórum de votação qualificado (OLIVEIRA, 2017, p. 193).

Esta dimensão encontra respaldo na obra de Oliveira, que alerta sobre a adequação da lei complementar, dada sua necessidade de quórum qualificado para aprovação, impedindo assim, por exemplo, "a contradição de se autorizar por lei ordinária a administração pública de adotar medidas nos moldes dos precedentes que são de competências de disciplinamento por lei complementar, como em matéria tributária (OLIVEIRA, 2017, p. 193).

Dessa forma, estar-se-ia respeitando o formalismo externado pelo princípio da legalidade. A utilização de lei delegada também é refutada, pois não é abstrata e trata de singularidades (OLIVEIRA, 2017, p. 7).

O entendimento do autor não merece reparos quanto a necessidade de lei complementar dada as suas características, isto daria conformidade constitucional quanto a legalidade, mas em nosso humilde modo de pensar, não daria uniformidade no território nacional, podendo assim cada munícipe ou morador de Estado ficar a mercê da norma legislada de uma respectiva câmara ou assembleia legislativa. 
Portanto, é imperioso apontar que a aplicação do precedente judicial obrigatório não irradia efeitos diretos quanto ao modo de operação dos atos da administração pública, excetuados aqueles precedentes que possuem assento constitucional, e, em sendo assim, as modalidades de precedentes obrigatórios do Código de Processo Civil só poderão vincular os atos administrativos quando munidos de regulamentação, visto que, mesmo sendo o códex processual uma lei, esta por sua vez, não tem força de suplantar as competências legislativas contidas na Constituição Federal, tão caras ao princípio federativo.

No mesmo passo, é importante destacar que a encampação através de lei complementar dos precedentes pela administração pública deve ficar adstrito àqueles comandos insertos pelo artigo 927, incisos III, IV e V do Código de Processo Civil de 2015:

\footnotetext{
III - os acórdãos em incidente de assunção de competência ou de resolução de demandas repetitivas e em julgamento de recursos extraordinário e especial repetitivos; IV - os enunciados das súmulas do Supremo Tribunal Federal em matéria constitucional e do Superior Tribunal de Justiça em matéria infraconstitucional; $\mathrm{V}$ - a orientação do plenário ou do órgão especial aos quais estiverem vinculados (BRASIL, 2015).
}

Essa delimitação torna-se benéfica não só pelo respeito literal da lei, mas também por dar coerência ao Direito.

Não está aqui a se defender uma fragilização do princípio da igualdade, onde uns são beneficiados com as respostas jurisdicionais enquanto outros ficam a mercê do indigesto texto legal, que de fato, por vezes, não atende aos direitos fundamentais do cidadão.

A proposta aponta para outra direção, onde existe sim uma observância aos direitos fundamentais propagadas pelos precedentes obrigatórios, entretanto, para uma correta aplicação, deve ser concretizado a luz dos princípios constitucionais, notadamente, o da legalidade, separação dos poderes e democrático. 


\section{POSSIBILIDADE DE INTEGRAÇÃO DO PRECEDENTE JUDICIAL NA ADMINISTRAÇÃO PÚBLICA POR MEIO DE EMENDA CONSTITUCIONAL}

Não é desconhecido que a Administração Pública vem adotando procedimentos em face da lógica de decisões do poder judicial encampando-as por lei ou mesmo por orientações administrativas.

Esta prática tem acorde com as mudanças de entendimento advindo de um texto constitucional democrático que deu centralidade ao discurso dos direitos humanos e direitos fundamentais.

Como efeito desta centralidade, nota-se um aumento maciço das questões discutidas pelo judiciário, em especial nas cortes de vértice com desdobramentos em vários seguimentos da sociedade, por exemplo, os setores da economia e a política.

Com o protagonismo do judiciário, notadamente em relação ao campo político, observa-se enfrentamentos que colocam em jogo o sistema adotado, tanto quanto as questões relacionadas à separação dos poderes, legalidade e o princípio democrático como em relação a própria eficácia e previsibilidade contida nas leis.

Vislumbra-se que "essa mudança é sentida especialmente na jurisprudência e no papel mais incisivo do Supremo especialmente quando deve decidir diferentemente do que foi decidido anteriormente pelo Legislativo ou Executivo" (BARBOZA, 2014, p. 265).

Todavia, a linha interpretativa do Direito, como sua aplicação, pode e deve transcender essa linha de colisão entre os poderes, para chegar-se a uma coalisão de entendimentos, em benefício da integridade e coerência do direito.

Esta boa prática pode ser conferida quando do julgamento pelo Tribunal Regional Federal da 4ํㅡㄹ Região ao tratar da matéria atinente "a equiparação dos companheiros homossexuais e heterossexuais perante a Previdência Social, com fundamento no princípio da dignidade da pessoa humana" (BARBOZA, 2014, p. 274), onde tal decisão favorável gerou, por sua vez, "a regulamentação pelo INSS por meio da Instrução Normativa n. 25 de 07/06/2000, dos procedimentos com vista à concessão de benefício ao companheiro ou companheira homossexual" (BARBOZA, 2014, p. 275).

Na mesma linha, a Receita Federal do Brasil, por meio do parecer da 
Procuradoria-Geral da Fazenda Nacional № 1503/2010, reconheceu a possibilidade de inclusão do companheiro homoafetivo como dependente, para fins de dedução do Imposto de Renda (PGFN, 2010).

Nota-se que a absorção do julgado pelo órgão administrativo apresenta-se como a ideia de integridade desejada, pois em um sistema de diálogo entre os poderes conquista-se uma resposta isonômica para a sociedade como um todo, e não só para aqueles que buscam a jurisdição.

Logo, a integridade possui raízes nos princípios, na linha jurisprudencial, e na seara política, fato que acaba gerando consistência na aplicação do Direito, pois se interpreta o Direito que se aplicara, indo para além das fronteiras antiquadas do antigo conceito de separação dos poderes, onde a norma legislada exercia império, como também impede uma exacerbação do juiz intérprete, que tenta construir a solução com base em suas convicções pessoais.

Outro exemplo de ampliação do diálogo entre os poderes está na Lei Paulistana, que assim dispõe no comando inserto do $\S 2^{\circ}$, do artigo 44-A da Lei 15.690/2013:

$\S 2^{\circ}$ O Presidente do Conselho Municipal de Tributos também poderá propor súmula, de caráter vinculante para todos os órgãos da Administração Tributária, decorrente de decisões definitivas de mérito, proferidas pelo Supremo Tribunal Federal em matéria constitucional ou pelo Superior Tribunal de Justiça em matéria infraconstitucional, em consonância com a sistemática prevista nos arts. 543-B e 543-C do Código de Processo Civil, não se aplicando a essa proposta o procedimento estabelecido no "caput" e no $\S 1^{\circ}$ deste artigo, observado o disposto nos $\S \S 3^{\circ}$, 4ํㅜ e 5ํำ deste artigo (São Paulo/SP, 2013).

O mecanismo legal ofertou condição isonômica para os contribuintes, eles estando ou não participando do debate processual; entretanto, apesar de a legislação local ter contribuído com o diálogo institucional entre os poderes, contribuindo na coesão e integração do direito, não consegue ela, por sua vez, gerar uniformidade em âmbito nacional, pois padece de limitação quanto ao poder de legislar referente a sua autonomia administrativa e âmbito de aplicabilidade.

Nessa medida, para dar expansão às decisões dos tribunais de vértice, sobretudo aquelas elencadas como sendo precedentes obrigatórios, incutidas no artigo 927 do Código de Processo Civil, sugere-se uma atualização constitucional 
advinda do poder constituinte de reforma.

Esta sugestão não possui como conclusão a ineficácia do artigo 927 do Código de Processo Civil, em um campo extraprocessual, como fonte orientadora da atividade administrativa, tanto é assim, que foram citados vários exemplos de inserção do entendimento firmado pelas cortes superiores na atuação administrativa.

A proposta aponta para outra direção, pois, por força constitucional, dever-se - ia aplicar na atividade administrativa as razões de decidir construídas a partir dos instrumentos do 927 do Novo Código de Processo Civil, e não só por intermédio de legislação local ou por instrumentos regulamentadores, ou mesmo somente pelo intérprete do interno da administração, que tem como opção doutrinaria aquela que entende que a força obrigatória do precedente extrai-se da própria carta constitucional, tornando-se assim a o precedente uma obrigação constitucional clara que força a Administração Pública a aplicar os entendimentos firmados na ratio decidendi dos precedentes obrigatórios no atuar da Administração.

Entende-se que a manifestação do poder constituinte derivado poderia alcançar uma voz de autoridade quanto à uniformidade do direito, e ainda complementaria a eficácia dos precedentes obrigatórios que passaria a ter um efeito erga omnes perante aos poderes e não só uma eficácia vinculativa em relação à jurisdição.

Isso acarretaria uma inovação da ordem jurídica, sem prejuízos aos princípios da legalidade, separação dos poderes e democrático e estaria em consonância com a coesão, integridade e estabilidade tão perseguidas no campo do Direito.

Esta característica reformadora atualizaria o sistema, exercendo uma "competência intermediária entre o poder constituinte originário e o poder legislativo comum" (BULOS, 2009, p. 314).

O poder derivado seria capaz de exercer um poder de atualização constitucional limitada pelo poder originário "adaptando os preceptivos supremos do Estado à realidade dos fatos" (BULOS, 2009, p. 314), ora, em um Estado Social Democrático, que dá centralidade a dignidade da pessoa humana e aos direitos fundamentais, seria incoerente uma não adaptação do texto constitucional apto a dar azo às mudanças no sistema jurídico em benefício da concretude de direitos.

De plano, verifica-se que a mudança do texto constitucional via poder 
secundário atenderia o princípio democrático tendo em vista a "titularidade do poder reformador pertencente ao povo" (BULOS, 2009, p. 314).

Desse modo, por meio de uma reforma específica, oriunda da técnica constitucional do artigo 60 da Constituição Federal, sugere-se a inclusão dos precedentes obrigatórios do artigo 927 do Código de Processo Civil, no rol constitucional, excetuados aqueles que já possuem lugar na carta magna, sendo eles os seguintes:

Art. 927. Os juízes e os tribunais observarão: (...) III - os acórdãos em incidente de assunção de competência ou de resolução de demandas repetitivas e em julgamento de recursos extraordinário e especial repetitivos; IV - os enunciados das súmulas do Supremo Tribunal Federal em matéria constitucional e do Superior Tribunal de Justiça em matéria infraconstitucional (BRASIL, 2015).

Tal medida ensejaria no aperfeiçoamento do sistema processual à medida que a interpretação jurisdicional sobre temas constitucionais e infraconstitucionais seria de observância obrigatória para todos os poderes tendo em vista o status constitucional e acomodaria e não suplantaria os ditames constitucionais da separação dos poderes, legalidade e o princípio democrático, e ainda, ofertaria maior segurança jurídica, celeridade e previsibilidade no regime jurídico administrativo e para sociedade que teria um tratamento isonômico perante o Estado como um todo e não só ante a um poder da República.

Adverte-se que esse poder reformador possui limitações explicitas e implícitas extraídas do próprio texto constitucional, nessa medida, deve-se observar que a atualização do sistema passa necessariamente pelo crivo desses limites para sua plena eficácia constitucional.

Logo o poder reformador não poderá descaracterizar "os limites expressos formais entabuladas na Constituição Federal no seu artigo 60 , I, II e III, $\S \S 2^{\circ}, 3^{\circ}$ e $5^{\circ}$, nem os circunstanciais disposto artigo $60, \S 1^{\circ}$ e materiais contido no artigo $60, \S 4^{\circ}$ referente a cláusula pétrea" (BULOS, 2009, p. 317).

$\mathrm{Na}$ mesma direção deverá obedecer aos limites implícitos referentes "ao poder reformador relacionado aos direitos e garantias fundamentais, titularidade do 
poder constituinte originário e reformador, e a necessidade de observância um processo legislativo especial de reforma" (BULOS, 2009, p. 317).

Percebe-se que a inclusão do rol de precedentes obrigatórios capitulados nos incisos III e IV do artigo 927 em rol constitucional, por meio do poder derivado, em nada ofende os limites explícitos e implícitos do alcance desse poder, em certa medida inclusive, rende homenagem, pois confere força ao plasmado no artigo 60 , $\S 4^{\circ} \mathrm{da}$ Constituição Federal, em ambiente de ordem processual, dando integridade ao Direito à luz do próprio texto constitucional.

A caminhada em busca de uma justiça célere e garantidora de segurança jurídica, por meio de mecanismo do poder derivando, não seria uma novidade em nosso sistema jurídico, tendo em vista as alterações encampadas na Emenda constitucional n. 45, de 30 de dezembro de 2004.

Onde a "Emenda Constitucional n. 45, de 30 de dezembro de 2004, alterou a redação do art. $102, \S 2^{\circ}$, da Constituição Federal para ampliar o efeito erga omnes e vinculantes também das decisões do Supremo Tribunal Federal proferidas em sede de ação direta de inconstitucionalidade" (BARBOZA, 2014 p. 279).

Na mesma linha, na Emenda constitucional n. 45, de 30 de dezembro de 2004, inseriu o art. 103 - A na Constituição Federal, gerando a possibilidade de criação pelo Supremo Tribunal Federal de súmulas vinculantes aos órgãos do Poder Judiciário e Administração Pública (BARBOZA, 2014 p. 280).

Verifica-se que o Código de Processo Civil, também caminha por uma trilha de respeito às decisões dos tribunais superiores numa constante busca de celeridade, segurança jurídica e tratamento isonômico de toda uma sociedade.

Nessa linha, são os dizeres da Comissão de Juristas Responsáveis pela Elaboração de Anteprojeto de Código de Processo Civil:

Esse o desafio da comissão: resgatar a crença no judiciário e tornar realidade
a promessa constitucional de uma justiça pronta e célere. Como vencer o
volume de ações e recursos gerando uma litigiosidade desenfreada, máxime
num pais cujo ideário da nação abre as portas do judiciário para a cidadania
ao dispor-se a analisar toda a lesão ou ameaça a direito? Como desincumbir-
se da prestação da justiça em um prazo razoável diante de um processo
prenhe de solenidades e recursos? Como prestar justiça célere numa parte
desse mundo de Deus, onde de cada cinco habitantes um litiga
judicialmente? (“...) São passos fundamentais para celeridade do Poder
Judiciário, que atingem o cerne dos problemas processuais, e que 
possibilitarão uma Justiça mais rápida e naturalmente, mais efetiva" (BRASIL. Congresso Nacional. Senado Federal. Comissão de Juristas Responsável pela Elaboração de Anteprojeto de Código de Processo Civil, Brasília: Senado Federal, Presidência, 2010) (BARBOZA, 2014 p. 279).

Apesar de não ser com a celeridade necessária, percebe-se que existem movimentações que tentam aperfeiçoar o sistema, no sentido de oferecer alternativas aptas a transformar e modernizar o sistema jurídico.

Contudo, não parece ser uma tarefa fácil a criação de um mecanismo formal que reúna condições aptas a fornecer uma celeridade, segurança jurídica e isonomia, por meio de atos administrativos respaldados nos precedentes obrigatórios, sem que não se ofenda os princípios constitucionais da legalidade, separação de poderes e o federativo.

Averigua-se essa dificuldade à medida que se visita as divergentes obras doutrinárias que meditam sobre 0 tema dos precedentes e 0 alcance de sua vinculatividade, tal problemática torna-se mais capciosa quando se questiona 0 alcance e eficácia dos dizeres dos precedentes obrigatórios para além dos muros da jurisdição.

Ainda em uma linha endoprocessual, existem aqueles que advogam pela interpretação de que o artigo 927 do novo Código de Processo Civil traz em seu significado linguístico uma vinculatividade expressa para os juízes e tribunais.

Nessa direção, aponta-se que "no Brasil, há precedentes com força vinculante - é dizer, em que a ratio decidendi contida na fundamentação de um julgado tem força vinculante. Estão eles enumerados no artigo 927 do Código de Processo Civil" (DIDIER JR; BRAGA; OLIVEIRA; 2017, p. 520).

Por outra via, residem aqueles que defendem que o comando inserto no artigo 927 do código de Processo Civil não exerce força vinculativa, pois entendem que a vinculação está somente nos precedentes que estão munidos com a prerrogativa da utilização do instituto da Reclamação encartado do artigo 988 do Novo Código de Processo Civil para exigir seu cumprimento (WAMBIER et al, 2015, p.1315).

Alexandre Freitas Câmara, por sua vez, discordando das duas linhas anteriores, afirma que o efeito vinculante não pode ser observado no artigo 927 do Código de Processo Civil, pois para o doutrinador o artigo só indica a necessidade de os juízes e tribunais considerarem o que ali está elencado, o que de fato vincula para 
o autor, são os precedentes que possuem um regime jurídico próprio para tanto.

Nessa medida, Câmara aponta:

\begin{abstract}
Que a eficácia vinculante não resulta do disposto no art. 927 do CPC. E é equivocada, data vênia, pensar que tal eficácia resultaria do fato de que o texto normativo do caput desse dispositivo afirma que os juízes e tribunais observarão o que consta dos incisos do aludido artigo de lei. A exigência, contida no caput do art.927, de que os órgãos jurisdicionais observarão o que ali está elencado indica, tão somente, a exigência de que tais decisões ou enunciados sumulares sejam levados em conta pelos juízes e tribunais em suas decisões. Em outras palavras, o art.927 cria, para os juízes e tribunais, um dever jurídico: o de levar em consideração, em suas decisões, os pronunciamentos ou enunciados sumulares indicados nos incisos do art. 927. Daí não resulta, porém, qualquer eficácia vinculante. Esta, quando existente, resultará de outra norma, resultante da interpretação de outro dispositivo legal (e que atribua expressamente tal eficácia). Não existindo essa norma, atributiva de eficácia vinculante, e a decisão ou o enunciado sumular será meramente persuasivo, argumentativo (e, portanto, não vinculante), o que gerará, para os juízes e tribunais - abrigados a observá-los em suas decisões - um ônus argumentativo: o de inserir, na decisão que deles se afaste, uma fundamentação especifica e adequada par tal afastamento, não sendo legitimo simplesmente que o juiz ou tribunal ignore aquele precedente ou enunciado sumular como se o mesmo não existisse (CÂMARA, 2017, P. 374).
\end{abstract}

Contrariando todas as linhas pretéritas, estão os doutrinadores que se posicionam no sentido de que seria o artigo 927 do Novo Código de Processo Civil inconstitucional, caso entenda-se que o artigo expõe precedentes obrigatórios de força formalmente vinculante.

A base que dá azo a esta afirmação é de que a força vinculante dos precedentes não poderia vir do Código de Processo Civil, mas sim do texto constitucional, conforme ocorre com as súmulas vinculantes e com o controle concentrado de constitucionalidade.

Weber Luiz de Oliveira:

No Brasil, essa característica de fonte do direito a impor respeito não só pela jurisdição, mas também pela administração e pelos particulares, é extraída do texto constitucional, com as súmulas vinculantes, consoante art. 103-A, e as decisões de controle concentrado, nos termos do art. 102, $\S 2^{\circ}$, da Constituição Federal (OLIVEIRA, 2016, p. 56).

José Rogerio Cruz e Tucci entalha que:

Daí em princípio, a inconstitucionalidade da regra, visto que a Constituição 


\begin{abstract}
Federal, como acima referido, reserva efeito vinculante apenas e tão somente às súmulas fixadas pelo Supremo, mediante devido processo e, ainda, aos julgados originados de controle direto de constitucionalidade (TUCCI, 2015, p. 454).
\end{abstract}

Por outro giro, existem vozes que destoam completamente das posições que defendem inconstitucionalidade do artigo 927do NCPC, ou que afirmam que os precedentes obrigatórios são aqueles que estão acobertados pelo instituto da Reclamação ou mesmo que seriam somente os precedentes elencados no artigo 927 do NCPC possuidores de força vinculantes.

Essas vozes afirmam que a formação do precedente é atividade exclusiva dos Tribunais Superiores e não se restringe a critérios formais ou referentes a repetições de processos similares, sendo que a formação de um precedente pode ser referente a outros critérios, ligados ao direito material e à qualidade representativa da discussão jurisdicional, "por essa razão, por exemplo, acaso um julgamento de recursos repetitivos não contenha razões determinantes e suficientes claramente identificáveis, não formará precedente, nada obstante oriundo da forma indicada pelo novo Código" (MITIDIERO, 2015, p. 04).

As referidas posições apesar de tratar com profundidade a sistemática da vinculação dos precedentes aferindo seus limites e possibilidades, não ofertam um denso entendimento teórico sob o ponto de vista extraprocessual, visto que trabalham em uma ótica interna do processo.

Todavia, a partir dos ensinamentos, retira-se extratos dos conhecimentos, anteriormente entalhados, passíveis de construir uma posição teórica relativa à vinculação da Administração Pública aos precedentes judiciais entabulados no artigo 927 do Novo Código de Processo Civil em um ambiente administrativo.

Como exemplo tem-se o entendimento colhido nos dizeres de José Rogerio Cruz e Tucci no qual prescreve que a constituição reserva os efeitos vinculantes somente a súmula vinculante e ao controle concentrado de constitucionalidade (TUCCI, 2015, p. 454); no entanto, parece existir uma necessidade de revisão deste entendimento, visto que a criação do assento constitucional para esse mecanismo fora para vinculação dos demais poderes e não só o poder judiciário.

Logo, concorda-se que o efeito vinculante dos mecanismos do artigo 927 NCPC carece de uma previsão constitucional, exceto quanto ao poder judiciário, 
sendo que inexiste impeditivo constitucional para que juízes e Tribunais estejam vinculados aos precedentes.

Ronaldo Cramer assevera:

\begin{abstract}
Esquecem-se os defensores dessa corrente que a previsão constitucional da força vinculante da decisão de controle concentrado de constitucionalidade e da súmula vinculante deu-se pelo fato de que esses precedentes não vinculam apenas o Poder Judiciário, mas também a Administração Pública direta e indireta, o que inclui o Poder Executivo. Assim, a eficácia vinculante desses precedentes tinha que ter assento constitucional, porque interfere na separação dos Poderes (CRAMER, 2016, p. 189). (...) Com exceção dos incisos I e II, respectivamente, a decisão de controle concentrado e a súmula vinculante, os demais precedentes do art. 927 do NCPC vinculam apenas o próprio judiciário. A vinculação do judiciário por um precedente emitido por ele próprio constitui hipótese de autorregramento e comporta apenas previsão infraconstitucional. Afinal, um poder pode autorregrar-se por lei federal (CRAMER, 2016, p. 190).
\end{abstract}

Desse modo, percebe-se que o caput do artigo 927 do NCPC de fato possui efeito vinculante, mas excetuados o controle concentrado de constitucionalidade e a súmulas vinculantes nele arroladas, as demais previsões constantes no caput do artigo precisavam ter amparo constitucional para vincular os demais poderes, caso contrário, ofender-se-ia os princípios constitucionais da separação dos poderes, legalidade e o democrático.

Rememora-se que a característica propositiva do trabalho não é excluir a Administração Pública do alcance das previsões elencas no caput do artigo 927 do NCPC, mesmo quanto aquelas que não estão descritas na constituição, entretanto, deve-se inserir o conteúdo das razões de decidir de um precedente na administração obedecendo aos ditames constitucionais.

A introdução destes precedentes judicias como baliza orientadora das atividades administrativas, enriqueceria a Administração Pública por vários ângulos, seus atos teriam maior segurança jurídica, pois estariam em consonância com a interpretação judicial, haveria maior isonomia em relação ao tratamento com a sociedade, visto que não haveria respostas distintas emitidas pelos poderes, diminuiria o custo da máquina pública tendo em vista o alto grau de litigância da Administração. Assim, esses ingredientes trariam eficiência para a atividade administrativa e dariam tons de previsibilidade quanto à eficácia de seus atos.

Os desdobramentos positivos quanto à inserção do entender judicial na 
atividade administrativa não são taxativos e vão além da esfera pública, haja vista que, mesmo as atividades do setor privado, necessitam de uma voz de coerência, integridade e estabilidade relacionada ao direito para melhor exercício de suas atividades.

Como também não pode se admitir em um Estado dito social, comprometido constitucionalmente com os direitos fundamentais e a dignidade da pessoa humana, um prejuízo causado somente pelas interpretações divergentes dos poderes, que podem acabar acarretando um atraso na prestação social, de obrigação Estatal.

A forma não pode preponderar em relação à substância, a tão almejada concretude dos direitos materiais, deve ser constantemente perseguida, inclusive pelas atualizações no campo processual.

No entanto, as atualizações necessárias carecem de base constitucional, especialmente, no caso do sistema de precedentes apresentados pelo NCPC, para fim de dar capilaridade necessária para atingir não só as partes do processo ou vincular juízes e tribunais, mas sim vincular toda a Administração Pública, por meio do instrumento da emenda constitucional, no intuito de transportar a interpretação qualificada de um precedente para o bojo administrativo.

Essa conversação entre os poderes afasta as ofensas aos princípios constitucionais, já devidamente indicados, e confere estabilidade, coerência e integridade ao direito, não só em espaço endoprocessual, mas também extraprocessual.

Nessa esteira, segue o entendimento de Nelson Jr. e Rosa Maria de Andrade Nery:

O objetivo almejado pelo CPC 927 necessita ser autorizado pela CF. Como não houve modificação na CF para propiciar ao Judiciário legislar, como não se obedeceu ao devido processo, não se pode afirmar a legitimidade desse instituto previsto no texto comentado. Existem alguns projetos de emenda constitucional em tramitação no Congresso Nacional com o objetivo de instituírem súmula vinculante no âmbito do STJ, bem como adotar-se a súmula impeditiva de recurso (PEC 358/05), ainda sem votação no parlamento. Portanto, saber que é necessário alterar-se a Constituição para criar-se decisão vinculante todos sabem. Optou-se, aqui, pelo caminho mais fácil, mas inconstitucional. Não se resolve problema de falta de integração da jurisprudência, de gigantismo da litigiosidade com o atropelo do due process of law. Mudanças são necessárias, mas devem constar de reforma constitucional que confira ao Poder Judiciário poder para legislar nessa magnitude que o CPC, sem cerimônia, quer lhe conceder" (NERY JR e 
ANDRADE, 2015, p.1837).

A posição dos autores parece ser parcialmente acertada, visto que aparentemente não existe óbice em criarem-se decisões vinculantes dentro das estruturas do judiciário, pois se trata de um auto regramento em nome da segurança jurídica e isonomia relativa ao tratamento com os jurisdicionados. Logo, nesse ponto específico, parece ser a crítica dos autores supramencionados um apego demasiado ao antigo conceito de separação dos poderes.

Todavia, em um ambiente não processual, a vinculação dos atos administrativos às decisões judicias clama por previsão constitucional, pois aqui incide a necessidade ao respeito da separação dos poderes, em sentido contrário, estaria por se admitir uma substituição de legitimados no exercício de um poder, ocupando o judiciário um papel que constitucionalmente está definido como de legitimidade legislativa.

Portanto, para absorver as vantagens oriundas dos precedentes obrigatórios pela administração pública, deve-se: a) observar o princípio da legalidade, como também, a inafastável responsabilidade do Estado quanto à concretude dos direitos fundamentais; b) criar mecanismo apto a harmonizar os poderes, no sentido de não se permitir a invasão de competências constitucionalmente definidas; c) respeitar o princípio democrático e federativo consagrados pelo texto constitucional.

Nesse diapasão, identificados os limitadores da introdução dos precedentes obrigatórios na atividade administrativa, resta necessário apontar as possibilidades e possíveis benefícios.

Portanto, defende-se que a possibilidade de uma vinculação formal da Administração Pública aos precedentes obrigatórios deva acontecer por meio de emenda constitucional, para que não haja ofensa a separação dos poderes, legalidade e o princípio democrático e, ao mesmo tempo, o mecanismo do poder constitucional derivado exerça uma papel de uniformização e concretização da interpretação do Direito em relação aos poderes que, por conseguinte, irão gerar respostas isonômicas e céleres nas relações individuais, coletivas e institucionais. 


\section{CONCLUSÃO}

Já é cediço que os precedentes judiciais de estatura vinculante ou persuasiva têm uma grande importância dentro da operacionalização do Poder Judiciário, irradiando efeitos positivos quanto a uniformidade, celeridade e coerência do direito.

Tais efeitos positivos acabam por externar uma racionalidade judicial, que por sua vez, transmite uma segurança jurídica tanto no campo do direito público como no campo privado, evitando assim uma justiça lotérica de entendimentos contraditórios.

Entretanto, no campo do Direito Público, mais especificamente no que tange a aplicação dos precedentes obrigatórios na administração pública, defende-se, uma inafastável observância do princípio da legalidade.

Assim, revela-se uma problemática, no sentido de que poderia suplantar-se 0 princípio da legalidade em nome de uma visão de proveito dos benefícios da aplicação dos precedentes obrigatórios no seio da Administração Pública, mesmo sem um suporte legal ou constitucional para tanto? Ou, por outra via, deveria afastar as razões de decidir de um precedente obrigatório, visto ter sua origem no poder judiciário e não no legislativo, pois ofende de forma direta a legalidade, separação dos poderes e o princípio democrático?

Aparentemente, sem a devida ponderação ou possível adequação, caminharemos por uma trilha de não conformação constitucional.

É consabido que a legalidade estrita não consegue dar suporte suficiente para modernização de todo uma sociedade que é assistida pela administração pública, logo, os precedentes judiciais obrigatórios elencados no artigo 927 do Código de Processo Civil, podem ser de grande valia quando integrados na maneira de agir da administração.

Entretanto, a busca de uma voz uníssona do direito, dada a integração de precedente judicial obrigatório nas atividades administrativas dependem de uma formatação especifica para ser constitucionalmente admitido.

A falta de norma que dê base ao uso de um precedente obrigatório pela administração pública, abala negativamente a separação de poderes, não sob o aspecto eminentemente legalista apegado aos ideais do século XVIII e XIX, mas sim no que diz respeito às limitações de poder, sendo que a falta de previsão para dar 
suporte a aplicação direta de um precedente gera um poder exacerbado do judiciário, que é vocacionado a interpretar o direito em relação aos casos concretos e não de produzir normas abstratas que é vocação típica do poder legislativo.

Logo, o instrumento da Emenda constitucional, teria eminentemente a função de transportar as razões de decidir de um precedente judicial por uma via sedimentada pelo princípio democrático, separação dos poderes e o da legalidade para ser corretamente encampado pela administração pública, que por sua vez produzira atos isonômicos mesmo para aqueles que não adentraram no judiciário buscando o seu direito.

Assim, mesmo em um espaço extraprocessual, o conteúdo decisório que originariamente vinculava tão somente a jurisdição, poderá passar a vincular, agora com o devido suporte, a administração pública.

Percebe-se que mesmo estando previsto os precedentes judiciais em uma lei processual,

a mesma não tem poder para tratar de assuntos intrínsecos a Administração Pública que por força constitucional estão no âmbito de competência legislativa dos entes federativos.

A partir desse raciocínio, interpreta-se que a Emenda Constitucional para encampar a ratio de um precedente obrigatório seria o mais adequado, visto evitar uma inadequação entre a matéria absorvida do precedente judicial e o mecanismo formal.

Ademais, é de suma importância à delimitação de quais precedentes obrigatórios terão efeito vinculante erga omnes, sendo este também um desdobramento do princípio da legalidade, visto que, os precedentes obrigatórios possíveis de encampação deverão somente ser aqueles eleitos pela lei de Processo Civil, dando coerência na integração do direito entre os poderes.

Também não é demais afirmar que esta encampação do precedente deve ser amplamente difundida pela administração pública, em homenagem ao princípio da publicidade e o da segurança jurídica.

Portanto, para haver conformação constitucional na aplicação de um precedente judicial obrigatório na Administração, exceto aqueles que já possuem assento na Constituição Federal, deverá existir uma ponte formal tendo com pedra 
angular a Emenda constitucional, autorizado assim, incutir os precedentes elencados pelo artigo 927 do Código de Processo Civil de 2015, nas atividades administrativas.

\section{REFERÊNCIAS}

BARBOZA, Estefânia Maria de Queiroz. Precedentes Judiciais e Segurança Jurídica: fundamentos e possibilidades para a jurisdição constitucional brasileira. São Paulo: Saraiva, 2014.

BULOS, Uadi Lammêgo. Curso de Direito Constitucional. 4. Ed. reformulada e atualizada de acordo com a Emenda Constitucional n. 57/2008. São Paulo: Saraiva, 2009.

BRASIL. Conselho Nacional de Justiça. Os 100 maiores litigantes. Brasília: CNJ, 2011. Disponível em <http://www.cnj.jus.br/images/pesquisasjudiciarias/pesquisa_100_maiores_litigantes.pdf>. Acesso em 20/10/2018.

. Constituição Federal de 1988. Promulgada em 5 de outubro de 1988. Disponível em <http://www.planalto.gov.br/ccivil 03/constituicao/constituição.htm>.

Disponíve

LEI № 13.105, DE 16 DE MARÇO DE 2015. Código de Processo Civil. 2018/2015/Lei/L13105.htm>. Acesos em 16 nov. 2018.

CÂMARA, Alexandre Freitas. Levando os padrões decisórios a sério: Formação e Aplicação de Precedentes e Enunciados de Súmula. ed. São Paulo: Atlas, 2018.

CRAMER, Ronaldo. Precedentes judiciais e teoria dinâmica.ed. Rio de Janeiro: Forense, 2016.

DAVID, Rene. Os grandes sistemas do direito contemporâneo, tradução de Hermínio A. Carvalho, 4 ed. São Paulo: Editora Martins fontes, 2002.

DIDIER JÚNIOR, Fredie; BRAGA, Paula Sarno; OLIVEIRA, Rafael Alexandria de. Curso de Direito Processual Civil. 12. ed. Salvador: JusPODIVM, 2017. v. 2.

LAMY, Eduardo; LUIZ, Fernando Vieira. Contra o aspecto prospectivo do precedente: uma crítica hermenêutica a frederick schauer. Revista de Processo, São Paulo, vol. 250/2015. p. 383 - 402, Dez. 2015.

MARINONI, Luiz Guilherme. A ética dos precedentes: Justificativa do novo CPC. São Paulo: Ed. RT, 2014. p. 115.

Precedentes obrigatórios. 3. ed. São Paulo: Editora Revista dos Tribunais, 2013. 
MEDINA, José Miguel Garcia. Integridade, Estabilidade e Coerência da Jurisprudência no Estado Constitucional e Democrático de Direito: O papel do precedente, da jurisprudência e da Súmula, à luz do CPC/2015. Revista dos Tribunais, vol. 974/2016. p. 2.

MELLO, Celso Antônio Bandeira de. Curso de Direito Administrativo, 27. ed. São Paulo: Malheiros, 2010.

MITIDIERO, Daniel. Precedentes, Jurisprudência e Súmulas no Novo Código de Processo Civil Brasileiro. Revista dos Tribunais Online, Revista de Processo, vol. 245, jul. 2015, p. $333-249$.

MODESTO, Paulo. O controle jurídico do comportamento ético da Administração Pública. Revista Eletrônica Sobre a Reforma do Estado, n. 10, jun.-ago. 2007, Salvador.

NERY JUNIOR, Nelson; ANDRADE, Rosa Maria. Comentários do Código de Processo Civil. Novo CPC - Lei13.105/2015. São Paulo: RT, 2015.

OLIVEIIRA, Weber Luiz de. Precedentes Judiciais na administração Pública Limites e possibilidades de aplicação. Salvador; Editora JusPodovim, 2017.

. Precedentes judiciais na administração pública. Revista de Processo, São Paulo, v. 41, n. 251, p. 429-455, jan. 2016.

PUGLIESE,Willian. Precedentes e a civil law brasileira: interpretação e aplicação do novo código de processo civil. São Paulo: Editora Revista dos Tribunais, 2016.

SÃO PAULO (Município). Lei no 15.690, de 15 de abril de 2013. Altera os arts. 29, $43,49,50,54,55,58,59,60,63$ e 65, bem como a tabela "a" do anexo II, todos da lei no 14.107, de 12 de dezembro de 2005, que dispõe sobre o processo administrativo fiscal e cria o conselho municipal de tributos; acresce o art. 44-a e revoga o $\S 6^{\circ}$ do art. 55, 0 art. 56 e 0 anexo I da mesma lei. Disponível em: <https://leismunicipais.com.br/a/sp/s/sao-paulo/lei-ordinaria/2013/1569/15690/leiordinaria-n-15690-2013-altera-os-arts-29-43-49-50-54-55-58>. Acesso em 28 nov. de 2018.

STRECK, Lenio Luiz. Súmulas no Direito Brasileiro: eficácia, poder e função: a ilegitimidade constitucional do efeito vinculante. 2. ed. Porto Alegre: Livraria do Advogado, 1998

TEREZA Arruda Alvim. Interpretação da Lei e de Precedentes: Civil Law e Common Law. Revista de Processo, São Paulo, vol.1, 2010.

TUCCI, José Rogério Cruz e. Direito Processual Civil Europeu contemporâneo. José Rogério Cruz e Tucci Coordenador. São Paulo: Lex, 2010. 
TUCCI, José Rogério Cruz e. O regime do precedente judicial e o novo CPC. DIDIER JR, Fredie. et al. (coord.). Precedentes. Salvador: Juspodivm, 2015.

WAMBIER, Teresa Arruda Alvim et al. Primeiros comentários ao novo Código de processo civil: artigo por artigo: de acordo com a Lei 13.256/2016. 1. ed. rev., atual. e ampl. São Paulo: Revista dos Tribunais, 2015.

ZANETI JR., H. PEREIRA., C, F,B. Por que o Poder Judiciário não legisla no modelo de precedentes do Código de Processo Civil de 2015? Revista de Processo. São Paulo, v. 257, 2016, p. 371-388, 2016. 